\title{
ERNEST LAPOINTE
}

Mackenzie King's Great Quebec Lieutenant 


\section{Also by Lita-Rose Betcherman}

The Swastika and the Maple Leaf: Fascist Movements in Canada in the Thirties

The Little Band: The Clashes between the Communists and the Political and Legal Establishment in Canada, 1928-1932 


\section{Ernest Lapointe}

Mackenzie King's Great

Quebec Lieutenant

LITA-ROSE BETCHERMAN

UNIVERSITY OF TORONTO PRESS

Toronto Buffalo London 
www.utppublishing.com

(C) University of Toronto Press Incorporated 2002

Toronto Buffalo London

Printed in Canada

ISBN 0-8020-3575-2 (cloth)

(6)

Printed on acid-free paper

\section{National Library of Canada Cataloguing in Publication Data}

Betcherman, Lita-Rose, 1927-

Ernest Lapointe : Mackenzie King's great Quebec lieutenant

Includes bibliographic references and index.

ISBN 0-8020-3575-2

1. Lapointe, Ernest, 1876-1941. 2. Canada - Politics and government 1921-1930. 3. Canada - Politics and government-1930-1935. 4. Canada Politics and government - 1935-1948. 5. Cabinet ministers - Canada Biography. 6. Canada. Parliament. House of Commons - Biography. I. Title.

FC581.L36B48 $2002 \quad 971.063^{\prime} 2^{\prime} 092 \quad$ C2001-903683-3 F1034.3.L36B49 2002

University of Toronto Press acknowledges the financial assistance to its publishing program of the Canada Council for the Arts and the Ontario Arts Council.

This book has been published with the help of a grant from the Humanities and Social Sciences Federation of Canada, using funds provided by the Social Sciences and Humanities Research Council of Canada.

University of Toronto Press acknowledges the financial support for its publishing activities of the Government of Canada through the Book Publishing Industry Development Program (BPIDP). 
To my husband, Irving Betcherman 
This page intentionally left blank 